\title{
The Use of Role-Play to Improve Speaking Ability at MTs Samarinda
}

\author{
Sumaningsih \\ IAIN Samarinda \\ Email: suma.almuna@gmail.com
}

\begin{abstract}
The preliminary study in teaching speaking at MTs AlMuna Samarinda was not satisfied; the students were reluctant to speak English, were shy and not confident to express ideas orally, and were afraid of being ridiculed by their friends. Their speaking skills' average score was 63.06, and it was below the minimum passing grade, that is, 70. This study tried to improve the students' ability to speak through role-play. The action research was carried out in two stages. The instruments of the study are observation, documentation, and speaking test. The findings of the study show that role-play could improve the students' speaking ability. It was proven by improving their speaking skill, from 63.06 in the preliminary study up to 76.6 in cycle II.
\end{abstract}

Keywords: speaking, ELT, role-play

\begin{abstract}
Abstrak: Hasil studi pendahuluan dalam pembelajaran speaking di MTs AlMuna Samarinda tidak memuaskan; siswa enggan berbicara bahasa Inggris, mereka malu-malu dan tidak percaya diri untuk mengungkapkan ide secara lisan, dan mereka takut ditertawakan oleh teman-temannya. Nilai rata-rata keterampilan berbicara siswa adalah 63,06 dan berada di bawah nilai kelulusan minimal yaitu 70. Penelitian ini berusaha untuk meningkatkan kemampuan berbicara siswa melalui permainan peran. Penelitian tindakan ini dilakukan dalam dua siklus. Instrumen penelitian adalah observasi, dokumentasi, dan tes berbicara. Temuan penelitian menunjukkan bahwa permainan peran dapat meningkatkan kemampuan berbicara siswa. Hal itu dibuktikan dengan peningkatan kemampuan berbicara mereka dari 63,06 pada pembelajaran pendahuluan menjadi 76,6 pada siklus II.
\end{abstract}

Kata-kata kunci: speaking, ELT, bermain peran

\section{Introduction}

English plays an important role today. English is a language widely spoken by people all over the world. This language is used in various areas of life; politics, 
economy, society, education, to culture. Entering the MEA (Asian Economic Community) era, more and more people feel the need to learn and master English to communicate with different people from Asia countries. For that reason, it is essential to learn 
English in schools in Indonesia. Including learning English in Madrassas is ultimately considered to be very important ${ }^{1}$.

Learning English in schools refers to the Indonesian national education system, which is the basis of education for all people in Indonesia. Learning English is carried out to provide foreign language skills and goes a long way toward increasing the knowledge and potential possessed by Indonesians. In the sense of educating the nation's life, Law Number 20 of 2003 concerning the National Education System mandates that national education functions develop capabilities and shape the character and civilization of the nation with dignity. Education is carried out to develop the potential of students to become human beings who have faith and devotion to God Almighty, have a noble character, are healthy, knowledgeable, capable, creative, independent and become democratic and responsible citizens.

There are 4 (four) skills in learning English, namely reading, listening, writing and speaking. All skills are essential and support each other. Mastery of the four English language skills is vital to show the extent of mastery of English by students. At the Madrasah Tsanawiyah level, these four English skills are taught to students. At the MTs level, mastery of English also determines mastery of English at the next level. English proficiency at the high school/ vocational/high school level or college is determined when students learn English at this high school level. A good foundation in high school will make it easier for students at higher levels to master English.

The national curriculum states that the core competencies of learning English are processing, presenting, and reasoning in the concrete realm (using, unravelling, arranging, modifying, and making) and the abstract realm (writing, reading, counting, drawing and composing) according to what is learned in schools and other sources in the same perspective/theory.

Meanwhile, students' basic competencies in learning English must master: 1) Compiling simple oral texts to pronounce and respond to expressions asking for attention, checking to understand, and appreciating good performance by paying attention to social functions, text structure, and elements. Correct language and in context. 2) Compiling oral and written texts to state and inquire about the ability and willingness to take any action, considering social functions, text structure, and linguistic elements that are correct and in context. 3) Compiling simple oral and written texts to state, ask, and respond to expressions of giving instructions, inviting, prohibiting, and asking for permission, considering social functions, text structure, and linguistic elements that are correct and in context. 4) Capture the meaning of personal invitations and greeting cards, very short and straightforward. 5) Compiling the written text of personal invitations and congratulations (greeting cards), concise and straightforward, considers social functions, text structure, and linguistic elements correct and in context. 6)

1 Wakhid Nashruddin, Teaching English as A Foreign Language at Madrasah Ibtidaiyyah: Facts and Challenges, Dinamika Ilmu, Vol. 15, no. 1, 2015. 
Compiling oral and written texts to state and inquire about the existence of an indefinite number of people, objects, animals, taking into account social functions, text structures, and linguistic elements that are correct and in context. 7) Compiling oral and written texts to state and inquire about actions/events that are carried out / occur regularly or are general truths, considering social functions, text structures, and linguistic elements that are correct and in context. 8) Compiling oral and written texts to state and inquire about actions/events that are being carried out / taking place at this time, taking into account social functions, text structures, and linguistic elements that are correct and in context. 9) Compiling oral and written texts to state and inquire about causal and inverse relationships, considering social functions, text structures, and linguistic elements that are correct and in context. 10) Compiling oral and written texts to state and inquire about the comparison of the number and nature of people, animals, objects, taking into account social functions, text structures, and linguistic elements that are correct and in context. 11) Capturing meaning in oral and written descriptive texts, short and straightforward. 12) Compiling oral and written descriptive texts, short and simple, about people, animals and objects, considers social functions, text structures, and linguistic elements that are correct and in context. 13) Compiling oral and written texts to state and ask questions about actions /events that were carried out / happened in the past, taking into account social functions, text structures, and linguistic elements that are correct and in context. 14) Capturing the meaning of oral and written recount text, short and simple, about activities, incidents, events. 15) Compiling oral and written recount texts, short and simple, about activities, incidents, events, taking into account social functions, text structure, and linguistic elements that are correct and in context. 16) Capturing the meaning of short messages and announcement/notification (notice), very short and straightforward. 17) Develop writing short text messages and announcement/notification (notice), concise and simple, with attention to social functions, the structure of the text, and the correct linguistic elements and context. 18) Capturing the meaning of an oral and written narrative text in the form of short and straightforward fables. 19) Capture the meaning of the song.

The curriculum above shows that students are expected to describe something or reveal events or events that occur either orally or in writing. However, not all students can do it. Many MTs students/students have difficulty understanding and expressing English verbally (speaking). This includes the challenges that students at MTs AlMuna Samarinda face. Students' unwillingness to consider English subject matter is frequently due to English teachers' lack of knowledge of different English teaching strategies and their ability to promote students' interest in learning English.

In reality, students' increased interest and encouragement would make it easier for them to learn and master English. In practice, many English students or learners struggle to master English, especially speaking, in many schools or 
educational institutions. Sayuri ${ }^{2}$ found there was anxiety and excitement in speaking English. Dian et $\mathrm{al}^{3}$ found the same thing. Shiauping Tian \& Masykur Mahmud $^{4}$ found the same thing as Sayuri and Dian et al. Cucu Sutarsyah ${ }^{5}$ has a similar claim. Besides that, Umar Fauzan \& Nadia ${ }^{6}$ stated the same thing if problems were expressing English.

The preliminary research results to determine the map of students' ability to speak English at MTs Al-Muna showed that most students were shy and did not dare to speak English. They have difficulty expressing vocabulary and telling events or what they have experienced in English. Students seem afraid to speak English. Not all students master English as expected, especially speaking ability (Speaking). The average class score in English lessons was 63.06. This is under the $\mathrm{KKM}$, which is 70 .

Meanwhile, the class limitation is $40 \%$. There are 12 students from a total of 30 students who can achieve mastery learning. The cause of the failure to teach English is since the teacher has not maximized the English teaching method. Teachers often use the lecture or question and answer method. Learning English must rely on the use of applicable and exciting methods. Engaging learning will captivate children to continue and feel at home learning English. Teachers must also be professional to achieve learning goals ${ }^{7}$.

Solutions should be sought to solve the problems, especially in English language learning and speaking skills in MTs Al Muna Samarinda. One of the changes that can be made is to use the role-play method in learning to speak (speaking). The method is very suitable to be applied when the teacher is learning to speak with the help of role cards. This method directs students to speak English ${ }^{8}$.

Role-play is a learning model directed at solving problems related to human relationships by playing specific roles. Students learn to cooperate, communicate actively, and interpret events through the roles they play. Students learn to explore relationships between humans by demonstrating and discussing them so that

${ }^{2}$ Sayuri, Problems in Speaking Faced by EFL Students of Mulawarman University, Indonesian Journal of EFL and Linguistics, vol 1, no. 1, May 2016.

3 Dian Eva Lestari, Bambang Loeneto, Diemroh Ihsan, The Correlation among English Learning Anxiety, Speaking and Writing Achievements of Senior High School Students. Indonesian Journal of EFL and Linguistics, Vol. 4 no. 2, November 2019.

${ }^{4}$ Shiauping Tian \& Masykur Mahmud. A Study of Academic Oral Presentation Anxiety and Strategy Employment of EFL Graduate Students. Indonesian Journal of EFL and Linguistics, Vol. 3no 2, November 2018.

${ }^{5}$ Cucu Sutarsyah. An Analysis of Student's Speaking Anxiety and its Effect on Speaking Performance. Indonesian Journal of English Language Teaching and Applied Linguistics, Vol. 1 no. 2, 2017.

${ }^{6}$ Umar Fauzan \& Nadia. The Challenges of Language Learning of the Study-Abroad Students of English Language Department of Islamic Higher Education in Kalimantan. Indonesian Journal of EFL and Linguistics, Vol. 4 no. 2, November 2019.

${ }^{7}$ Muhammad Nasir. Profesionalisme Guru Agama Islam: Sebuah Upaya Peningkatan Mutu Melalui LPTK. Dinamika Ilmu. Vol. 13 No 2, 2013.

${ }^{8}$ Hayriye Kayi. Teaching Speaking: Activities to Promote Speaking in a Second Language. The Internet TESL Journal, Vol. 12, No. 11, November 2006. 
together they can explore ideas, attitudes, values, and various problem-solving strategies according to the role situation they play.

As one of the learning methods in speaking, role-playing can improve students' speaking ability. Kuśnierek said that role-playing is able to develop students' speaking ability because they feel comfortable and happy with roleplaying. Almost all students said that their speaking ability had improved9. Meanwhile, Doang added that role-playing allows students to practice speaking English based on real-life situations. Students speak English more confidently, more naturally, and more fluently ${ }^{10}$.

Role-play is not just a two-way communication in the concept of sharing in the classroom. Role-play can also be applied to touch other aspects, such as context, development, character, or culture. In essence, all learning must pay attention to these aspects. Learning must be done contextually ${ }^{11}$ to improve aspects of student development ${ }^{12}$ and see what real situations or cultures the learners embrace or hold or what characters should be developed ${ }^{131415}$. Learning will also be effective if it uses appropriate media and teaching aids and tangible objects around the student's life ${ }^{16}$. Thus, learning English using techniques role-playing will run smoothly and achieve the desired results by all parties.

This is a classroom action research (PTK) project in English language learning, with a background in English language issues, specifically speaking skills (speaking) ${ }^{17}$. Students in class VIII MTs AlMuna Samarinda served as research subjects. Since there was an issue with teaching English, the study was conducted in the classroom.

Observation, documentation, and tests were used as instruments. Direct observations in class are used to collect data, which is then recorded using observation sheets and field notes. Examining all data sources relating to written data, such as student grades/report cards or other related documents, is how documentation is conducted. The test consists of a direct assessment of the

9 Anna Kuśnierek, Developing students' speaking skills through role-play, World Scientific News. 1, 2015, pp. 73-111.

10 Tham My Duong, An investigation into effects of role-play in an EFL speaking course, Global Journal of Foreign Language Teaching. Vol. 4, no. 2, 2014, pp. 81-91.

${ }_{11}$ M. Iwan Abdi, Contextual Teaching and Learning (CTL) dalam Pembelajaran PAI. Dinamika Ilmu. Vol. 11, no. 1, 2011.

12 Hamzah, Syeh Hawib. Aspek Pengembangan Peserta Didik: Kognitif, Afektif, Psikomotorik. Dinamika Ilmu, Vol. 12, no. 1, 2012.

13 Khairy Abusyairi. Pembelajaran Bahasa dengan Pendekatan Budaya. Dinamika Ilmu. Vol. 13, no. 2, 2013.

${ }^{14}$ Lulus Irawati. Applying Cultural Project Based Learning to Develop Students' Academic Writing. Dinamika Ilmu, Vol. 15, no. 1, 2015.

15 Siti Julaiha. Implementasi Pendidikan Karakter dalam Pembelajaran. Dinamika Ilmu, Vol. 14, no. 2, 2014.

16 Umar Fauzan. The Use of Improvisation technique to improve the Speaking ability of EFL students. Dinamika Ilmu, Vol. 14, no. 2, 2014.

17 Sitti Hadijah, Investigating the Problems of English Speaking of the Students of Islamic Boarding School Program at STAIN Samarinda. Dinamika Ilmu, Vol. 14, no. 2, 2014. 
students' speaking skills. Data was analyzed in two ways: descriptive data was used to describe all results in the observations, and simple statistical data was used to determine the average score of the students.

The research data was obtained in the form of observation data from role-playing observations of learning management and observations of student and teacher activities at the end of each cycle and student formative test data.

\section{Role-Playing}

Before teaching is carried out, first teaching preparation is carried out. At this stage, the researcher prepares learning tools consisting of lesson plans, worksheets, formative test questions, and supporting teaching tools. Then carried out learning English using techniques of role-playing. In this case, the researcher acts as a teacher. The teaching and learning process refers to the lesson plans that have been prepared. Observation (observation) is carried out simultaneously with the implementation of teaching and learning. At the end of the teaching and learning process, students are given a formative test to determine the level of student success in the teaching and learning process carried out.

The results of observations in cycle 1 showed that students initially were shy about doing role-playing. They did not seem to know what to say. This happens because they do not have enough vocabulary in English to express ideas and language expressions regarding the roles they have to play. They have got a role card and a series of conversations that they have to express in the form of roleplaying. However, many students forget the text they have to bring, so they often read the text. In general, cycle one has not shown the development of speaking skills, including fluency in it. However, it appears that there is a difference in the atmosphere of learning that is more positive when they learn to speak directly through role-playing.

The data on the results of research in cycle I conducted by researchers as a result of student learning before the implementation of the PTK (preliminary test) compared to the results of the cycle I are as follows:

Table 1

Data Comparison of Student Score in Cycle 1 and Pre-cycle

\begin{tabular}{|c|c|c|}
\hline Student Score & Pre-Tesst & Cycle 1 \\
\hline Average & 63.06 & 68.28 \\
\hline Lowest rated & 55 & 60 \\
\hline Top rated & 75 & 80 \\
\hline KKM & \multicolumn{2}{|c|}{70} \\
\hline
\end{tabular}

The table above shows that by applying the learning method role-play, the average value of student learning achievement is 68.28, and learning completeness reaches $57 \%$, or there are 17 students out of 30 students who have completed learning. These results indicate that in the first cycle classically, students have not finished learning because students who get a value of $\geq 70$ are only $57 \%$ smaller 
than the desired percentage of completeness which is $70 \%$. Students still feel new and do not understand what the teacher means and uses by applying the method role-play.

The results of the first cycle were used to guide reflection. In the first period, the students did not complete their learning. This highlights the need for role-playing learning to be improved or adjusted. Adjustments will be made in adjusting the role theme based on the life that is not far from the lives of students and the need for appropriate media that can support the learning process by playing roles.

In cycle II, in cycle II, the researcher prepares the learning tools before teaching, consisting of lesson plans 2, worksheets 2, formative test questions II, and supporting teaching tools.

After making preparations, then the implementation of learning English was carried out. In implementing this teaching, the researcher acts as a teacher. The teaching and learning process refers to the lesson plan by paying attention to the revision in cycle I so that mistakes or deficiencies in cycle I do not happen again in cycle II. Observation is carried out simultaneously with the implementation of teaching and learning. At the end of the teaching and learning process, students are given a formative test to determine the level of student success during the teaching and learning process carried out. The instrument used was a formative test.

The findings from cycle II revealed that learning to speak English by roleplaying differed significantly from learning in cycle I. Students were able to take on more parts, which made a difference. They aren't too clumsy or afraid to perform live and act in roles. While there was some stiffness at first, the students became more comfortable with this learning technique after conducting many role plays. Many students stopped reading the texts and instead memorized them, making them easier to pronounce and converse with. This is not the same as cycle I. More often than not, students seem to be merely reading.

The data on research results in cycle II, as well as a comparison of student learning outcomes before the implementation of the PTK (pre-test), cycle I, and learning outcomes at the end of cycle II, are as follows:

Table 2

Data Comparison of Student Score, Pre-cycle, Cycle I, and Cycle II

\begin{tabular}{|c|c|c|c|}
\hline Student Score & Pre-Test & Cycle I & Cycle II \\
\hline Average & 63.06 & 68.28 & 76.61 \\
\hline Lowest Rated & 55 & 60 & 60 \\
\hline Top Rated & 75 & 80 & 90 \\
\hline KKM & \multicolumn{3}{|l}{} \\
\hline
\end{tabular}

The table above indicates that using the learning method role-play, the average value of student achievement before implementing the action is 63.06 in English classes. Twelve students can reach mastery learning out of a total of 30 students. The average score of student learning achievement at the end of the first 
cycle was 68.28, and 17 students out of 30 had completed their studies. The average student learning achievement score at the end of cycle II was 76.61, and 23 out of 30 students had completed their studies.

\section{Implementing Role-Play}

Before implementing the action, the average class score in English lessons at MTs AlMuna Samarinda was 63.06 under the KKM, 70. Meanwhile, the class limitations are $40 \%$, this number is from 12 students out of a total of 30 students who are able to achieve mastery learning. After applying the learning method role-play, it was found that the average value of student learning achievement was 68.28, and learning completeness reached $57 \%$, or there were 17 students out of 30 students who had finished learning. These results indicate an increase. Even so, in the first cycle, classically, the students had not finished learning. Students who get a value of $\geq 70$ are only $57 \%$ smaller than the desired percentage of completeness, which is $70 \%$. Then proceed to Cycle II. At the end of this second cycle, the average score of student learning achievement was 76.61, and 23 out of 30 students had completed their studies.

A visual comparison of the differences in students' English skills can be seen from the graphic below.

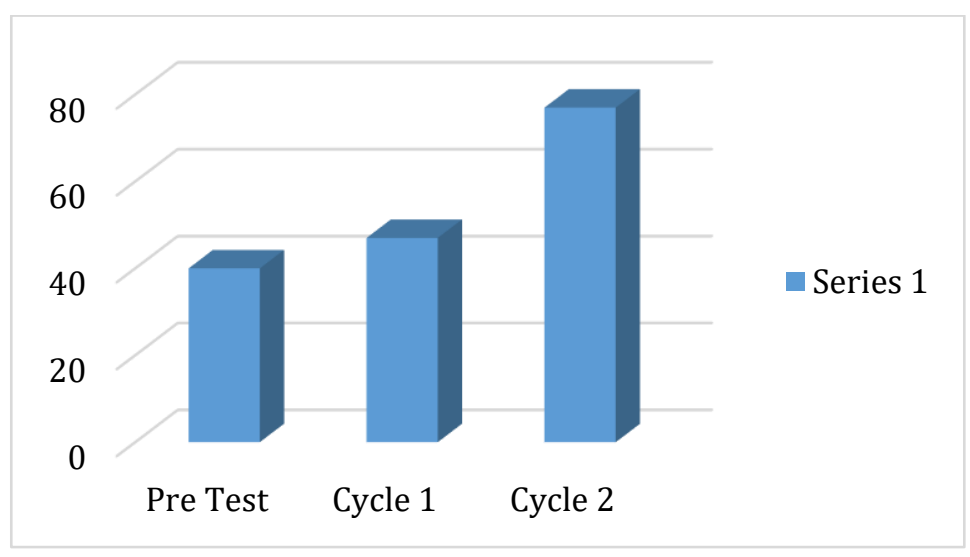

Picture: Comparison of the English Proficiency of Mts Almuna students

This study proves that role-playing is effective for use in English language learning classes, especially speaking skills. This finding is in accordance with the findings of Kuśnierek ${ }^{18}$, and the findings of Duong ${ }^{19}$. However, they still consider and adjust to the conditions of each typical class, such as what was conveyed by Bharathy that role-play is effective. If the class is not too big, you must pay attention to passive students, and the teacher must provide examples and the right concepts to improve students' abilities ${ }^{20}$ or use media such as pictures ${ }^{2122}$.

${ }^{18}$ Anna Kuśnierek, Developing students', 2015.

${ }^{19}$ Tham My Duong, An investigation into effects of role-play, 2014

${ }^{20}$ M.Shyamala Bharathy, Effectiveness of Roleplay in Enhancing Speaking Skills of Tertiary Level Learners. Journal of Humanities and Social Science (IOSR-JHSS) Vol. 13, no. 1, 2013. 
Role-play can be offered as a solution for English students or learners who have difficulty mastering English, especially speaking. Teachers can try to deal with problems of anxiety and difficulty in speaking English, such as the findings of Sayuri23, Dian et al. ${ }^{24}$, Shiauping Tian \& Masykur Mahmud ${ }^{25}$, Cucu Sutarsyah ${ }^{26}$, or Umar Fauzan \& Nadia27 where the anxiety can be tried to be resolved by implementing Role-play.

Role-playing can, of course, be combined with strategies, techniques, or learning media. The combination helps make learning more exciting and entertaining, such as drama, as Dwi Astuti Wahyu Nurhayati28 discovered, the use of YouTube, as Yuli Nurmala Sari \& Margana Margana ${ }^{29}$ explored, the use of authentic material ${ }^{30}$, or the need to improve the teacher's ability, as Teguh Budiharso ${ }^{31}$ mentioned.

\section{Closing}

From the results of learning activities carried out for two cycles, and based on the entire discussion and analysis, the role-playcan enhance the ability to speak (speaking) student/student MTs Almuna. Before implementing the action, the average class score in English lessons at MTs AlMuna Samarinda was 63.06. In the first cycle, the average value of student learning achievement was 68.28. At the end

21 DAW Nurhayati, Using Picture Series to Inspire Reading Comprehension for the Second Semester Students of English Department of IAIN Tulungagung. Dinamika Ilmu, Vol. 14, no 2, 2014.

22 Puguh Karsono, Using Pictures in Improving the Speaking Ability of the Grade Eight-A Students of SMP Negeri 1 Anggana. Dinamika Ilmu, Vol. 14, no. 2, 2014.

23 Sayuri, Problems in Speaking Faced by EFL Students of Mulawarman University. Indonesian Journal of EFL and Linguistics, Vol. 1, no. 1, May 2016.

24 Dian Eva Lestari, Bambang Loeneto, Diemroh Ihsan, The Correlation among English Learning Anxiety, Speaking and Writing Achievements of Senior High School Students. Indonesian Journal of EFL and Linguistics, Vol. 4, no. 2, November 2019.

25 Shiauping Tian \& Masykur Mahmud, A Study of Academic Oral Presentation Anxiety and Strategy Employment of EFL Graduate Students. Indonesian Journal of EFL and Linguistics, Vol. 3, no. 2, November 2018.

26 Cucu Sutarsyah, An Analysis of Student's Speaking Anxiety and its Effect on Speaking Performance. Indonesian Journal of English Language Teaching and Applied Linguistics, Vol. 1, no. 2, 2017.

27 Umar Fauzan \& Nadia, The Challenges of Language Learning of the Study-Abroad Students of English Language Department of Islamic Higher Education in Kalimantan. Indonesian Journal of EFL and Linguistics, Vol. 4, no. 2, November 2019.

28 Dwi Astuti Wahyu Nurhayati, Using Local Drama in Writing and Speaking: EFL Learners' Creative Expression. Journal of English Language Teaching and Linguistics, Vol. 1, no. 1, April 2016.

29 Yuli Nurmala Sari \& Margana Margana, YouTube as a Learning Media to Improve the Student's Speaking Ability in 21st Century. Journal of English Language Teaching and Linguistics, Vol. 4, no. 2, August 2019.

30 Sri Fatmaning Hartatik \& Tities Hijratur Rahmah, Investigating the Students' Views on the Authentic Materials Used in Basic Speaking Class. Indonesian Journal of English Language Teaching and Applied Linguistics, Vol. 1, no. 1, 2016.

31 Teguh Budiharso, The Oral Language Proficiency of Indonesian English Teachers. Indonesian Journal of English Language Teaching and Applied Linguistics, Vol. 4, no. 1, 2019. 
of this second cycle, the average value of student learning achievement was 76.6. The key to learning using role-playing in cycle II is a change or adjustment to the implementation of learning. Adjustments are made in adjusting the role theme based on the life that is not far from the life of students and the use of appropriate media that supports the learning process using role-playing.

\section{Bibliography}

Abdi, M I, Contextual Teaching and Learning (CTL) dalam Pembelajaran PAI. Dinamika Ilmu. Vol. 11, no. 1, 2011.

Abusyairi, Khairy, Pembelajaran Bahasa dengan Pendekatan Budaya. Dinamika Ilmu. Vol. 13, no. 2, 2013.

Bailey, K. M. Speaking, In Nunan, David (Editor), Practical English Language Teaching. Singapore: McGraw-Hill, 2003.

Bharathy, M.Shyamala, Effectiveness of Roleplay in Enhancing Speaking Skills of Tertiary Level Learners. Journal of Humanities And Social Science (IOSR-JHSS), Vol. 13, no. 1, 2013.

Budiharso, Teguh, The Oral Language Proficiency of Indonesian English Teachers, Indonesian Journal of English Language Teaching and Applied Linguistics, Vol. 4, no. 1, 2019.

Burns, A. \& Joyce, H, Focus on Speaking, Sidney: National Centre for English Language Teaching and Research Macquarie University, 1999.

Duong, Tham My, An investigation into effects of role-play in an EFL speaking course, Global Journal of Foreign Language Teaching, Vol. 4, no. 2, 2014.

Fattah, Mustamin \& Yamin, H, M, Efektivitas Model Kooperatif untuk Meningkatkan Kemampuan Membaca Teks Bahasa Arab Mahasiswa PESKAM STAIN Samarinda, Fenomena, Vol. 6, no. 1, 2014.

Fauzan, Umar, Developing EFL Speaking Materials for the Second Semester Students of STAIN Samarinda. Proceedings of $61^{\text {th }}$ TEFLIN International Conference, UNS Surakarta, October 2014.

Fauzan, Umar, The Use of Improvisation technique to improve the Speaking ability of EFL students, Dinamika Ilmu, Vol. 14, no. 2, 2014.

Fauzan, Umar \& Nadia. 2019. The Challenges of Language Learning of the StudyAbroad Students of English Language Department of Islamic Higher Education in Kalimantan. Indonesian Journal of EFL and Linguistics, Vol. 4, no. 2, November 2019.

Hadijah, Sitti, Investigating the Problems of English Speaking of the Students of Islamic Boarding School Program at STAIN Samarinda. Dinamika Ilmu, Vol. 14, no. 2, 2014.

Hamzah, Syeh Hawib, Aspek Pengembangan Peserta Didik: Kognitif, Afektif, Psikomotorik. Dinamika Ilmu, Vol. 12, no. 1, 2012.

Hartatik, Sri Fatmaning \& Rahmah, Tities Hijratur, Investigating the Students' Views on the Authentic Materials Used in Basic Speaking Class, Indonesian 
Journal of English Language Teaching and Applied Linguistics, Vol. 1, no. 1, 2016.

Irawati, Lulus, Applying Cultural Project Based Learning to Develop Students' Academic Writing, Dinamika Ilmu, Vol. 15, no. 1, 2015.

Julaiha, Siti, Implementasi Pendidikan Karakter dalam Pembelajaran. Dinamika Ilmu, Vol. 14, no. 2, 2014.

Karsono, Puguh, Using Pictures in Improving the Speaking Ability of the Grade Eight-A Students of SMP Negeri 1 Anggana, Dinamika Ilmu, Vol. 14, no. 2, 2014.

Kayi, Hayriye, Teaching Speaking: Activities to Promote Speaking in a Second Language, The Internet TESL Journal, Vol. 12, no. 11, November 2006.

Kuśnierek, Anna, Developing students' speaking skills through role-play. World Scientific News, 1, 2015.

Lestari, Dian Eva, dkk, The Correlation among English Learning Anxiety, Speaking and Writing Achievements of Senior High School Students. Indonesian Journal of EFL and Linguistics, Vol. 4, no. 2, November 2019.

Nasir, Muhammad, Profesionalisme Guru Agama Islam: Sebuah Upaya Peningkatan Mutu Melalui LPTK, Dinamika Ilmu, Vol. 13, no 2, 2013.

Nashruddin, Wakhid, Teaching English as A Foreign Language at Madrasah Ibtidaiyyah: Facts and Challenges, Dinamika Ilmu, Vol. 15, no. 1, 2015.

Nurhayati, Dwi Astuti Wahyu, Using Picture Series to Inspire Reading Comprehension for the Second Semester Students of English Department of IAIN Tulungagung. Dinamika IImu, Vol. 14, no. 2, 2014.

Nurhayati, Dwi Astuti Wahyu, Using Local Drama in Writing and Speaking: EFL Learners' Creative Expression. Journal of English Language Teaching and Linguistics, Vol. 1, no. 1, April 2016.

Sari, Yuli Nurmala \& Margana, YouTube as a Learning Media to Improve the Student's Speaking Ability in 21st Century, Journal of English Language Teaching and Linguistics, Vol. 4, no. 2, August 2019.

Sayuri, Problems in Speaking Faced By EFL Students of Mulawarman University, Indonesian Journal of EFL and Linguistics, Vol. 1, no. 1, May 2016.

Sudiarti, Sri, Peningkatan Keterampilan Membaca Teks Arab Gundul melalui Aktifitas Membaca Intensif Berbasis Gramatikal: Studi Kasus Mahasiswa Bahasa dan Sastra Arab IAIN STS Jambi, Fenomena, Vol. 7, no.1, 2015.

Sutarsyah, Cucu, An Analysis of Student's Speaking Anxiety and its Effect on Speaking Performance. Indonesian Journal of English Language Teaching and Applied Linguistics, Vol. 1, no. 2, 2017.

Thornbury, Scott, How to Teach Speaking, England: Pearson Education Limited, 2005.

Tian, Shiauping \& Mahmud, Masykur, A Study of Academic Oral Presentation Anxiety and Strategy Employment of EFL Graduate Students, Indonesian Journal of EFL and Linguistics, Vol. 3, no. 2, November 2018. 